\title{
Experimental Study of the Performance of Base Metal and Welding LiNe OF THE HOUSEHOLD L. P. G. CYLINDERS MANUFACTURED IN KURDISTAN REgION
}

\author{
Yassin Mustafa Ahmed ${ }^{1}$; Hameed D. Lafta ${ }^{2}$; Azhin Abdullah Abdul Rahman ${ }^{3}$; \\ Barzan Talib Salih ${ }^{4}$ \\ Sulaimani Polytechnic University, \\ Technical College of Engineering, Department of Mechanical Engineering \\ Sulaimani, Kurdistan region, Iraq \\ e-mail: ${ }^{1}$ yassin.ahmed@ @ spu.edu.iq; ${ }^{2}$ hameed.lafta@ spu.edu.iq; \\ 3azhinabdullah92@gmail.com; ${ }^{4}$ barzan69@gmail.com
}

\begin{abstract}
Liquefied petroleum gas (propane or butane) is a colorless liquid which readily evaporates into a gas. It has no smell, although it will normally have an odor added to help detect leaks. Liquefied petroleum gas is stored and handled as a liquid when under pressure inside an LPG cylinder. Liquefied petroleum gas cylinders are subjected to various tests to ensure their compliance requirements as per standard. This research studies the durability of welding and performance of base metal of L. P. G. home cylindrical in Kurdistan region. The experiments were carried out on three types of LPG cylinders used in Kurdistan regions: A, B, and C and an unformed plate. To carry out the samples and tests during the research, we relied on the standard tests for LPG cylinders. Three samples are extracted from each of LPG cylinders and an unformed plate for each of tensile test, Bending test and Hardness test according to ISO 6892-2016 and ASME standards from each type of LPG cylinders and from unformed plate to examine the mechanical properties. In addition, chemical compositions were also carried out. These values are compared with the standard.
\end{abstract}

\section{Keywords}

LPG; ASTM; ASME; ISO; BS 5045.

\section{Introduction}

Liquefied Petroleum Gas (LPG) is a colorless liquid which readily evaporates into a gas. It has no smell, although it will normally have an odor added to help detect leaks. When mixed with air, the gas can burn or explode when it meets a source of ignition. It is heavier than air, so it tends to sink towards the ground [1]. LPG is composed predominantly of a mixture of hydrocarbons such as propane, propylene, butane or butylene. The gas can be liquefied at moderate pressure, and can be stored in cylinders as a liquid under pressure and is drawn out and used as gas. This means that it can be transported and stored as liquid and burnt as gas. The expansion ratio of gas liquid is 270:1 at atmospheric pressure. The expansion factor makes LP-gas more economical to be transported and stored with large quantities of gaseous fuel in a small container. Containers are normally filled by $80-85 \%$ liquid, leaving $15-20 \%$ vapor space for expansion due to temperature increase. The household gas cylinder weighs approximately $14 \mathrm{~kg}$. Nowadays, composite materials have been used widely, which is proved to be more effective. These composite materials are wound over metal liner thus acting as an over wrapped composite pressure vessel. LPG cylinder is one kind of a pressure vessel that stores pressurized gases. LPG cylinder material should have high tensile and compressive 
strength for withstanding the high pressure of the gases [2]. The Cylinders play a crucial role in containing and transporting hazardous LPG from the filling plant to the end consumer [3].

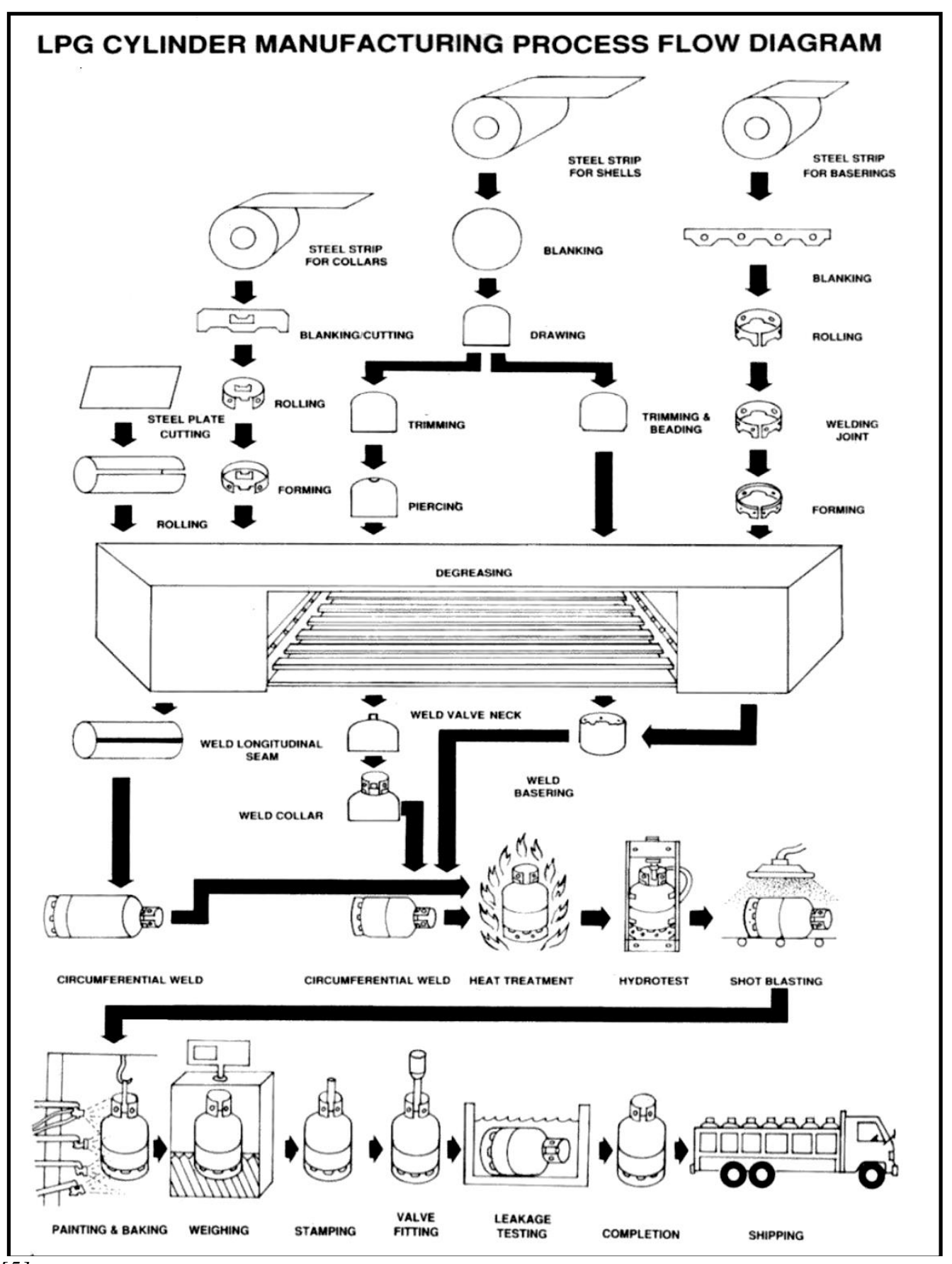

Source: [5]

Fig. 1: The process of manufacturing of LPG cylinders

LPG Cylinders are to be manufactured from definitely prescribed raw material to ensure safety of cylinders through material quality specifications [4]. Although there are clear standards and statutory norms for design, manufacturing and usage of cylinders, there are certain gaps in these standards in terms of ensuring material safety compliance. LPG cylinder production is composed of several sheet metal forming, surface treatment and testing processes. The process starts with blanking, deep drawing and piercing, trimming and joggling. Next are the welding operations for valve boss, valve guard ring, foot ring and the two halves. The finished cylinder is then heat treated, tested, shot blasted, painted and then the 
valve is attached and tested finally [5]. The main steps involved in manufacturing process of LPG cylinders are shown in Fig. 1.

\section{$1 \quad$ Literature Review}

Liquefied petroleum gas (LPG) cylinders that have an important position from the point of use have been taken into consideration, therefore, as explained below, intensive research has been carried out by the researchers Siddiquia, Ramakrishna and Lalc [6] who investigated a study on the welded low-carbon steel cylinders exceeding 5 liters of water capability which was produced and tested as per Indian Standard (IS 3169).

Lalc, Ramakrishna and Siddiquia [7] conducted several tests on LPG cylinders, in which the acceptance test is one of the most important tests to reveal cylinder parent metal mechanical properties. Two tensile specimens are prepared from finished cylinder batch for this test and tested on a universal testing machine to determine yield strength, percentage elongation and ultimate tensile strength of parent metal. Values of these test results are compared to standard values prescribed in Indian standards to decide acceptance of cylinder batch for market release.

Mahmud et al. [8] have studied the effect of annealing temperature on the mechanical properties of SG 255 steel. The SG 255 steel is used in manufacturing of domestic LPG cylinder in Kurdistan region. Furthermore, their work aims to obtain experimentally better mechanical properties at particular ductility with lower annealing temperature and to minimize the cost of the manufacturing of LPG cylinders. A number of samples were made according to ISO 6892, and then heat treated with different annealing temperature $(850,900$, and $950{ }^{\circ} \mathrm{C}$ ). Moreover, the tensile tests of these samples were carried out until failure to obtain the mechanical properties. It was shown that higher elongation percentage $34.18 \%$ with an annealing temperature of $900{ }^{\circ} \mathrm{C}$ can be achieved, and this leads to minimizing the cost of manufacturing of the cylinders without degrading their quality.

Li et al. [9] proposed an integral manufacturing process with hot drawing and cold flow forming for large diameter seamless steel gas cylinders. The primary aim of this research was to find out the impacts of the manufacturing method on gas cylinders made of $34 \mathrm{CrMo} 4$ steel's microstructure and mechanical characteristics. Two preformed cylinders were produced by hot drawing. One cylinder was then further manufactured by cold flow forming. The experiments were carried out using three types of material samples, namely base material (BM), hot drawing cylinder (HD), and cold flow-formed cylinder (CF). Tensile and impact tests were performed to examine the mechanical properties of the cylinders in longitudinal and transverse directions. Microstructure evolution was analyzed by scanning electron microscopy (SEM) and electron backscatter diffraction (EBSD) to reveal the relation between the mechanical properties and the microstructure of the material. It was found out that the mechanical properties of the $34 \mathrm{CrMo} 4$ steel gas cylinders were significantly improved after hot drawing and flow forming plus a designed heat treatment, compared with the base material. The observations of microstructure features such as grain size, sub grain boundaries, and residual strain support the increase in mechanical properties due to the proposed manufacturing process.

\section{$2 \quad$ Research Subject}

In this study, an unformed plate and the sheet materials of liquefied petroleum gas (LPG) cylinders that have an important position from the point of use have been taken into consideration. The household LPG cylinders can be divided into two main groups, the first group imported by the central government and the second group locally produced in the 
Kurdistan region by different companies and in different cities. A group of specimens was taken from the unformed plate and base metal of the cylinders, while other ones were taken across the cylinders from the weld zone transversely in the middle of the cylinders, which had the same initial thickness of $3 \mathrm{~mm}$. It is worth mentioning that the effect of geometric discontinuities due to weld toe was eliminated since the thickness of entire samples was kept constant. Different test results are compared to the standard.

\section{$3 \quad$ Methodology}

\subsection{Materials}

The material of the LPG cylinders and unformed plate is low alloy carbon steel with $3 \mathrm{~mm}$ thickness. The mechanical and chemical composition required according to BS 5045 [10] is given in Tables 1 and 2 respectively.

Tab. 1: Mechanical properties of LPG cylinders

Source: [10]

\begin{tabular}{|l|l|}
\hline Mechanical properties of LPG cylinders & Value \\
\hline Minimum yield strength & $240 \mathrm{~N} / \mathrm{mm}^{2}$ \\
\hline Tensile strength & $360-430$ \\
\hline Minimum elongation & $30 \%$ \\
\hline
\end{tabular}

Tab. 2: Chemical composition of LPG cylinders

Source: [10]

\begin{tabular}{|l|l|}
\hline Chemical composition & \% max \\
\hline $\mathrm{C}$ & 0.16 \\
\hline $\mathrm{Mn}$ & 0.50 \\
\hline $\mathrm{Si}$ & 0.20 \\
\hline $\mathrm{P}$ & 0.03 \\
\hline $\mathrm{S}$ & 0.03 \\
\hline
\end{tabular}

\subsection{Chemical Composition Analysis}

To achieve this study, we used three LPG cylinders from different companies and different cities (B, C, D) and an unformed plate (A) to make the specimens. To distinguish between the LPG cylinders, and also to mention the name of the companies or cities, different letters are used. The letter (A) indicates the unformed plate, (B) is the letter used for the first cylinder, (C) is the letter for the second cylinder, and (D) is the letter for the third cylinder. The chemical compositions examination of the test specimens were achieved by spectrometry instrument, see Fig. 2. 
Source: Own

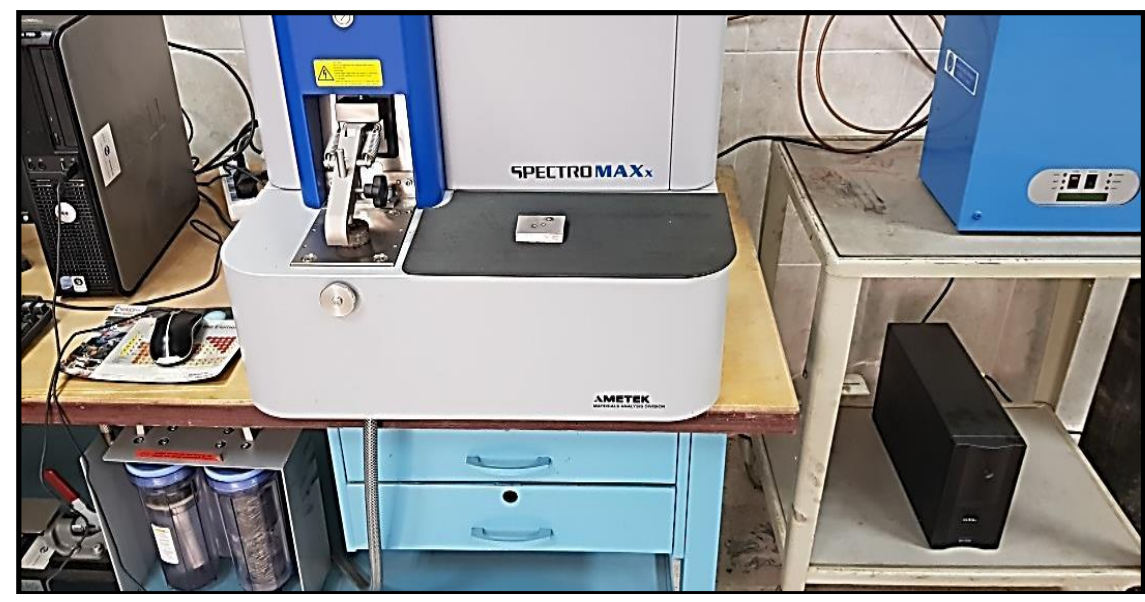

Fig. 2: Chemical composition of samples

The results of chemical composition are shown in Table 3.

Tab. 3: Chemical composition of LPG cylinders and unformed plate

Source: Own

\begin{tabular}{|l|c|r|r|r|r|}
\hline Sample & C \% & \multicolumn{1}{c|}{ Si \% } & \multicolumn{1}{c|}{ Mn \% } & \multicolumn{1}{|c|}{ P \% } & \multicolumn{1}{c|}{ S \% } \\
\hline A & 0.129 & 0.192 & 0.92 & $<0.0005$ & $<0.0005$ \\
\hline B & 0.119 & 0.082 & 1.05 & $<0.0005$ & 0.0054 \\
\hline C & 0.135 & 0.163 & 0.926 & 0.0005 & 0.0030 \\
\hline D & 0.124 & 0.181 & 0.966 & $<0.0005$ & 0.0034 \\
\hline
\end{tabular}

From the above-mentioned chemical compositions of cylinders and unformed plate, it can be seen in Table 3 that the contents of all elements, except for silicon and manganese in all samples were nearly the same. Sample (B) had a lower silicon content and higher manganese content than the other samples, since all cylinders came from different production batches and thus were likely to be from different raw steel sheet. With respect to the investigations of this work, these small deviations could be neglected. However, all the chemical contents of all cylinders and the unformed plate were in the acceptable range of the standard of steel grades used for LPG cylinder except manganese.

\subsection{Tensile Test}

The investigated LPG cylinders were manufactured by using deep drawing process from two low-carbon steel plates with a dome shape and an intermediate cylinder, which were subsequently welded together along the peripheral direction, see Fig. 1. Microstructure and mechanical behavior of the welding line were differed from the base low carbon steel and could considerably affect the structural integrity and performance of the LPG cylinder. Tensile testing was carried out at a room temperature of $23{ }^{\circ} \mathrm{C}$ as per ISO 6892-2016 [11]. The tensile test specimens with the gauge length of $50 \mathrm{~mm}$ were prepared from the sidewall of cylinders in the longitudinal direction. A group of specimen was taken from the base metal, while another one was taken across the cylinders and had the weld zone transversely in the middle according to ASME section IX 2013 [12], as shown in Fig. 3 and 4. 

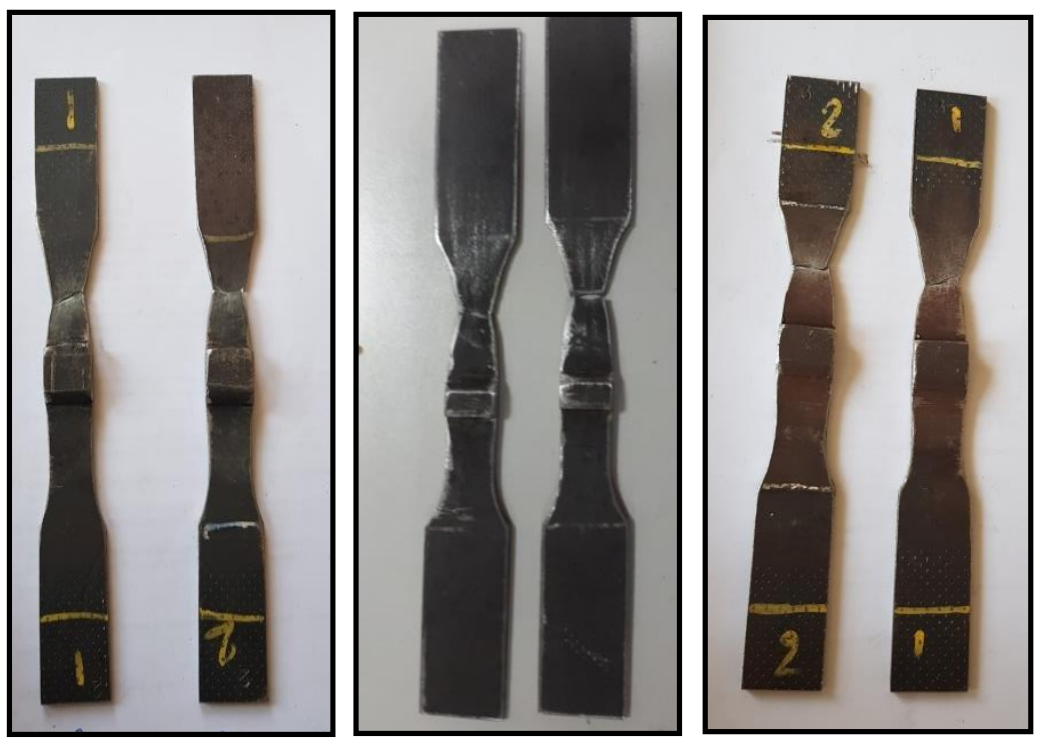

Source: Own

Fig. 3: Tensile test samples (weld metal)

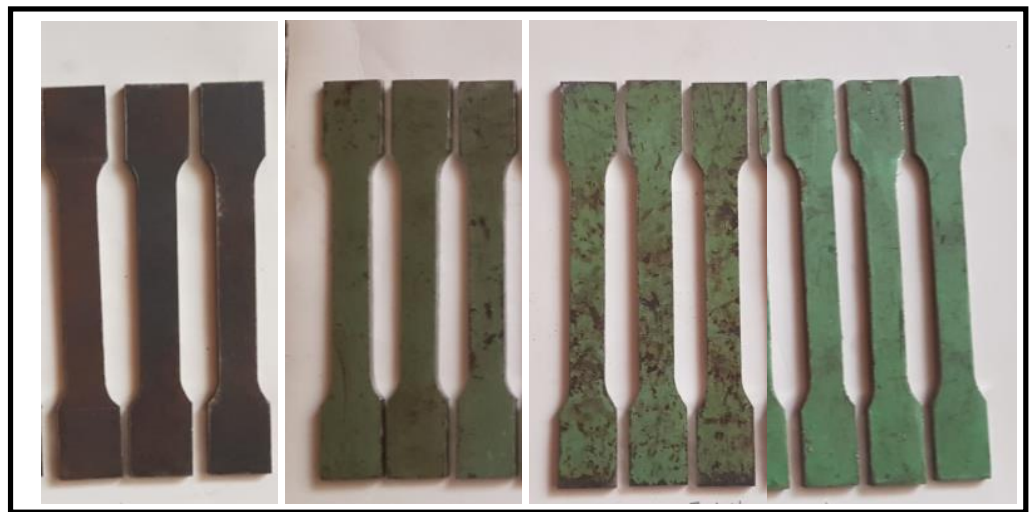

Source: Own

Fig. 4: Tensile test samples (base metal)

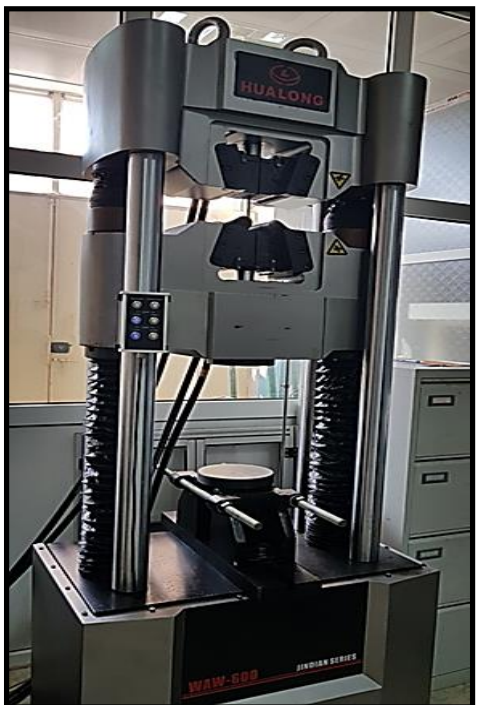

Source: Own

Fig. 5: Tensile test machine 
Note that the effect of geometric discontinuities due to weld toe was eliminated since the thickness of entire samples was kept constant. The tensile tests were carried out on a universal testing machine as shown in Fig. 5.

The achieved mechanical properties such as yield strength, tensile strength and elongation of the base metal and weld area of the specimens were presented in Tables 4 and 5 .

Tab. 4: The tensile test results of the cylinders and unformed plate (base metal)

\begin{tabular}{|l|c|c|c|}
\hline Sample & Ultimate strength (MPa) & Yield strength(MPa) & Elongation \\
\hline A & 456.86 & 325.56 & 33.80 \\
\hline B & 389.86 & 249.33 & 28.80 \\
\hline C & 417.20 & 283.33 & 25.90 \\
\hline D & 447.40 & 304.00 & 28.53 \\
\hline Standard & $(360-430)$ & $\min (240)$ & Min $(30) \%$ \\
\hline
\end{tabular}

Source: Own

By observing the tensile test results, we found out that the unformed metal (sample A) and sample (D) exhibited highest yield and tensile strengths whereas sample (B) had lower ultimate and yield strength while its elongation was similar to sample (D) and higher than of sample (C). Furthermore, the yield and tensile strengths of sample (C) were greatly higher than those of sample (B) while the elongations of sample (c) much decreased as compared to sample (A). It is obvious that the tensile properties especially the elongation of sample B, C, D were little different from BS 5045 standard [10] and the yield stress is higher than $240 \mathrm{MPa}$ in all cases; all gas cylinders are within the range of BS 5045 standard [10], however, the ultimate strength of sample (A), (D) is greater than that of the standard as shown in Table 4. It can be concluded that the subsequent forming process does not cause significant changes in the mechanical properties of the material after heat treatment.

Tab. 5: The tensile test results of the cylinders on welded area

\begin{tabular}{|l|c|c|c|}
\hline Sample & Ultimate strength (MPa) & Yield strength(MPa) & Elongation \\
\hline B (tensile shear strength) & 361.9 & 306 & 47.8 \\
\hline B (ASME) & 405.5 & 310 & 28.3 \\
\hline C (ASME) & 447.8 & 310 & 35.0 \\
\hline D (ASME) & 434.7 & 305 & 35.5 \\
\hline Standard & $(360-430)$ & $\min (240)$ & Min $(30) \%$ \\
\hline
\end{tabular}

Source: Own

On the other hand, from Table 5 it can be seen that the sample (C) and the sample (D) exhibited high ultimate tensile strengths and yield strength with similar elongation whereas sample (B) had lower ultimate tensile shear strength while its elongation was higher than of those samples. Furthermore, the elongation of sample (B) was much lower than those of the other samples. It is obvious that the tensile properties, especially the elongation of sample B, $\mathrm{C}$, and D, were little different from BS 5045 standard [10] and the yield stress is higher than $240 \mathrm{MPa}$ in all cases; all gas cylinders are within the range of BS 5045 standard [10]; however, the ultimate strength of sample (A), (D) is greater than that of the standard, as shown in Table 5. It is apparent that the material of the cylinders exhibits good ductility.

\subsection{Hardness Test}

The preparation of hardness test samples has been carried out with an appropriate cutting method, which involves selecting the correct cutting tool and using a cooling liquid to avoid the samples from burning and distortion. To cut and prepare the specimens for the hardness exam, a milling machine process with cooling liquid was used, see Fig. 6. 
Source: Own

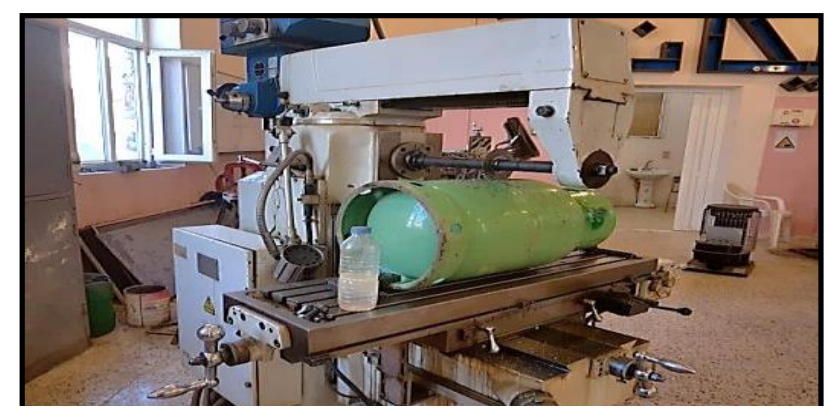

Fig. 6: Cutting process of LPG cylinders

After cutting, the samples were grinded and polished in order to prevent any scratches and to accomplish right reading. The Vickers hardness testing was carried out for different locations of the sample face to check the consistency and uniformity of the properties, see Fig. 7. The micro-hardness testing was carried out as per ASTM E384 [13] standard. Diamond indenter (pyramid) with face angle of $136^{\circ}$ was used. During testing $1 \mathrm{~kg}$ load was applied on sample with dwell time of 15 seconds, and both the diagonals of pyramid indenter (d1 and d2) were measured with a microscope at a magnification of 500X.

Source: Own

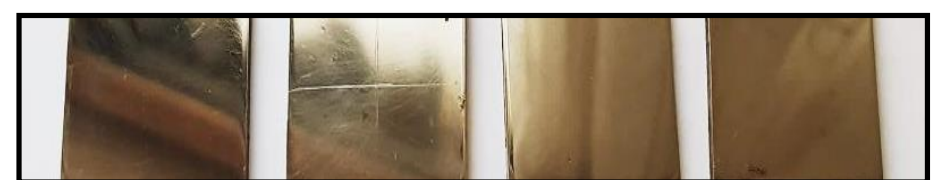

Fig. 7: Hardness test samples

The results of the hardness tests have shown in Table 6 and Fig. 8 respectively.

Tab. 6: Results of the average hardness test

Source: Own

\begin{tabular}{|l|c|}
\hline Sample & Average Vickers hardness $\left.\mathbf{( k g} / \mathbf{m m}^{\mathbf{2}}\right)$ \\
\hline Sample (A) & 147.24 \\
\hline Sample (B) & 153.28 \\
\hline Sample (C) & 142.70 \\
\hline Sample (D) & 162.66 \\
\hline
\end{tabular}

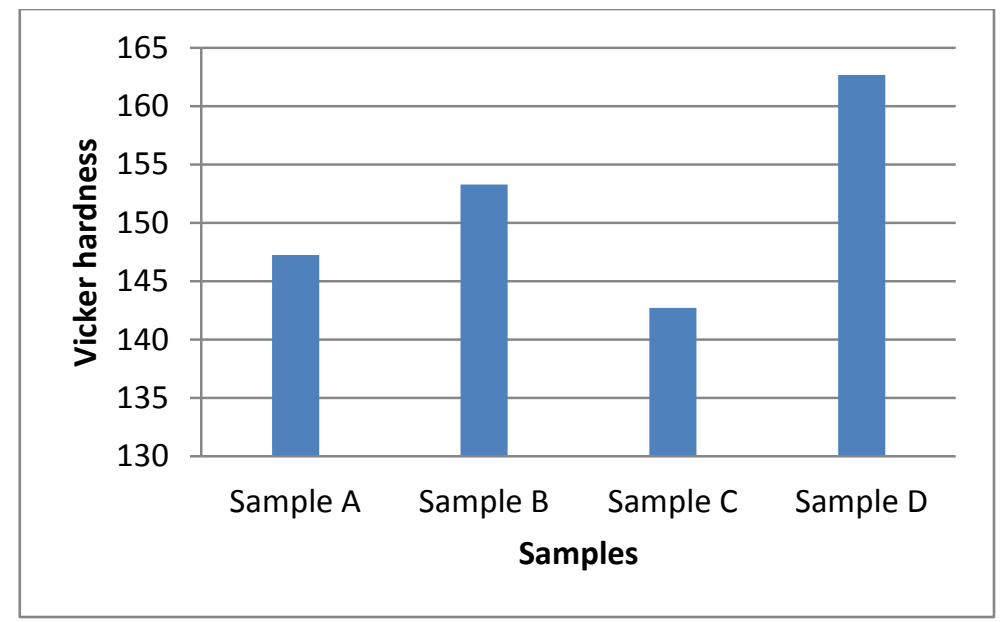

Source: Own

Fig. 8: The diagram of the Results of the hardness test of samples 
The average hardness results revealed that the values of (sample D) offered the highest value as compared to other samples while sample (C) shows the lower result as compared to others.

\subsection{Bending Test}

Bending test is a one of important tests that standard required to achieve. This test achieved perpendicular to the weld zone which has been bent through the angle of $180^{\circ}$. Bending tests for ductility provide a simple way to evaluate the quality of materials by their ability to resist cracking or other surface irregularities during one continuous bend condition. The bending tests were carried out in accordance with AWS standard [14] for all three LPG cylinders to evaluate their welding qualities. The results of such a test obtained by the same tensile machine, the bending test samples and machine are shown in Figures 9, 10, and 11.

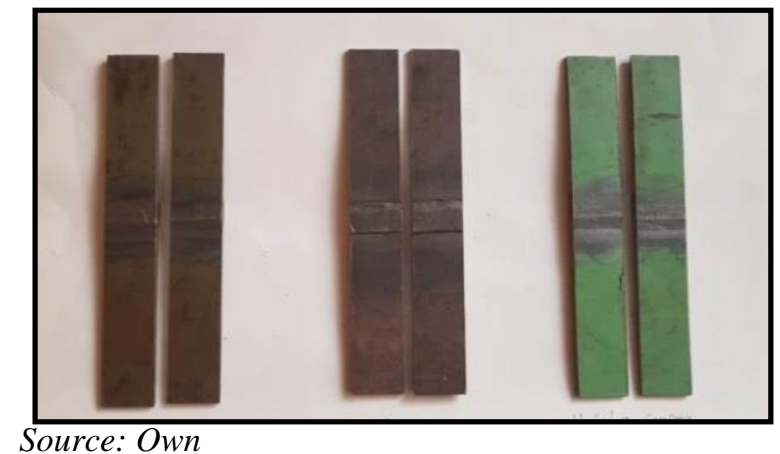

Fig. 9: Prepared bending test samples

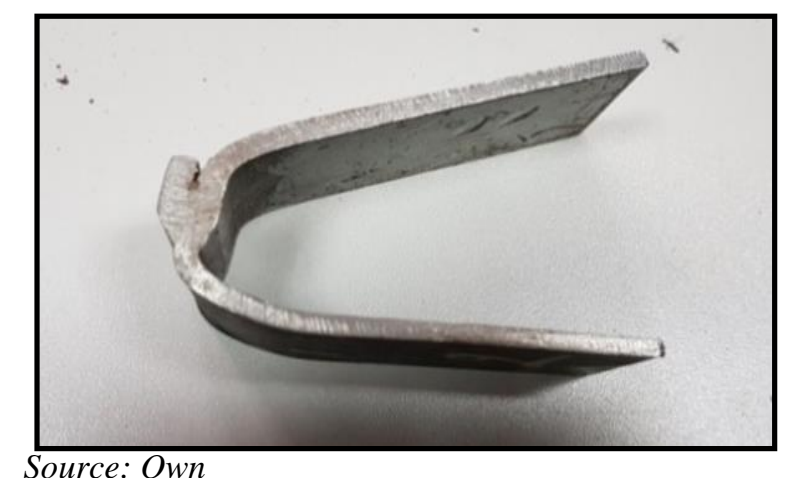

Fig. 10: Bending test sample

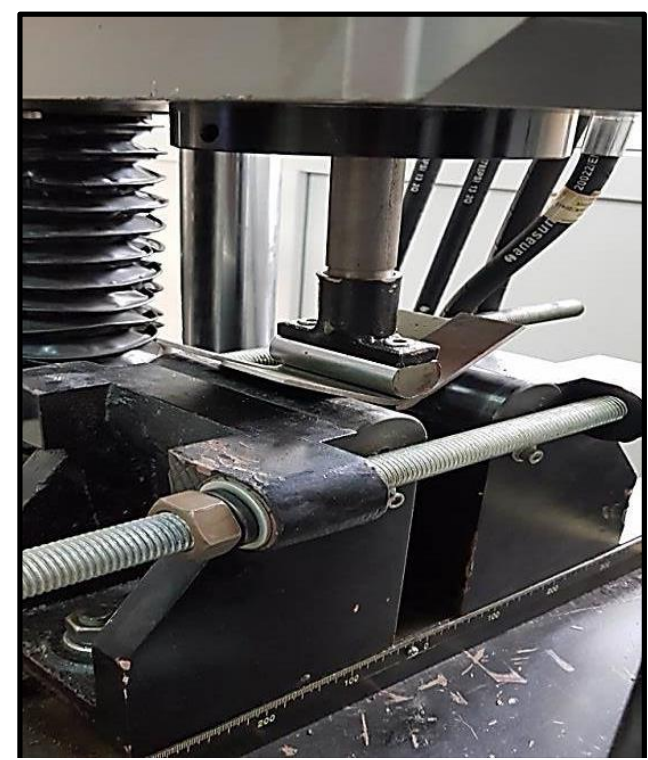

Source: Own

Fig. 11: Bending test machine

The bending test results showed that the samples were bent at 180 degrees without breaking or cracking in the samples. This means that the samples met the requirements of the standards. The ductility of weld was satisfactory and there are no defects in the welding joints for all samples.

\section{Conclusion}

Based on the results of tensile, hardness, bending tests, and chemical composition results of the current study it can be concluded that all the chemical contents of all cylinders and an 
unformed plate were in the acceptable range of the standard of steel grades used for LPG cylinder except manganese. In addition, the tensile properties of the unformed plate and base metal of the LPG cylinders were show little different from BS 5045 standard [10] and they are in the acceptable range. On the other hand, the ultimate tensile strength, yield strength and elongation of the weld metal of the LPG cylinders are nearly similar according to ASME standard. For the hardness test it is clear from the results that the average hardness values of sample (D) have recorded greatest value when compared with other samples. It can also be seen that the bending results showed that no development of crack was noticed during the bending test.

\section{Literature}

[1] TRIPATHI, A.; KUMAR, A.; CHANDRAKAR, M.: Design and Analysis of a Composite Cylinder for the Storage of Liquefied Gases. International Journal for Scientific Research \& Development. 2017, Vol. 5, Issue 3, pp. 871-876. Online ISSN 2321-0613.

[2] KIRAN, C. S.; SRUTHI, J.: Design and Finite Element Analysis of Domestic LPG Cylinder using ANSYS Workbench. CVR Journal of Science and Technology. 2018, Vol. 14, pp. 97-101. ISSN 2277-3916. DOI: $10.32377 /$ cvrjst1419

[3] NIYAMAT, M.; BICHA, K.: Design and Stress Analysis of Pressure Vessel by Using ANSYS. International Journal of Engineering Sciences \& Research Technology. 2015, Vol. 4, Issue 7, pp. 578-585. ISSN 2277-9655.

[4] RAMAKRISHNA, A.; SIDDIQUIA, N. A.; LALC, P. S.: Review of Liquefied Petroleum Gas (LPG) Cylinder Life Cycle. International Journal of Advanced Engineering Technology. 2013, Vol. 4, pp. 124-127.

[5] BUREAU OF INDIAN STANDARDS: Product Manual for Hot Rolled Steel Plate (up to 6 $\mathrm{mm}$ ), Sheet and Strip for the Manufacture of Low Pressure Liquefiable Gas Cylinders according to IS 6240:2008. [online]. 2020. Available from WWW: http://bis.gov.in/wp-content/uploads/2020/02/PM_IS_6240.pdf

[6] SIDDIQUIA, N. A.; RAMAKRISHNA, A.; LALC, P. S.: Review on Liquefied Petroleum Gas Cylinder Acceptance Test as per Indian Standard, IS 3196 (Part 3): 2012. International Journal of Advanced Engineering Technology. 2013, Vol. 4, pp. 119-123.

[7] LALC, P. S.; RAMAKRISHNA, A.; SIDDIQUIA, N. A.: Impact of Sample Preparation Methods on Liquefied Petroleum Gas Cylinder Parent Metal Tensile. Journal of Engineering Research and Studies. 2013, pp. 12-15.

[8] MAHMUD, F. J.; ABDULRAHMAN, K. M.; MUHAMMED, H. J.; SEED, B. A. H.: The Influence of Annealing Temperature and Soaking Time on the Ductility of SG 255. Kurdistan Journal of Applied Research. 2017, Vol. 2, Issue 3. Print ISSN 2411-7684. Electronic ISSN 2411-7706. DOI: 10.24017/science.2017.3.60

[9] LI, Y.; FANG, W.; LU, Ch.; GAO, Z., MA, X.; JIN, W.; YE, Y.; WANG, F.: Microstructure and Mechanical Properties of 34CrMo4 Steel for Gas Cylinders Formed by Hot Drawing and Flow Forming. Materials. 2019, Vol. 12, Issue 8. DOI: $\underline{10.3390 / \mathrm{ma1} 2081351}$ 
[10] BRITISH STANDARDS INSTITUTION: BS 5045-2:1978. Specification for transportable gas containers. Steel containers up to 130 litres water capacity with welded seams. [online]. 1978. Available from WWW: https://shop.bsigroup.com/ProductDetail/?pid=0000000000010100408

[11] ISO: ISO 6892-1:2016. Metallic materials - Tensile testing - Part 1: Method of test at room temperature. [online]. 2016. Available from WWW: https://www.iso.org/standard/61856.html

[12] ASME: ASME Boiler and Pressure Vessel Code. Section IX. [online]. 2013. Available from WWW: https://www.browntechnical.org/content/PDF/ASME BPVC-IX-2013.pdf

[13] ASTM: ASTM E384 - 11. Standard Test Method for Knoop and Vickers Hardness of Materials. [online]. 2011. DOI: 10.1520/E0384-11

[14] AMERICAN WELDING SOCIETY: Welding Handbook, Volume 1, Welding and Cutting Science and Technology. $10^{\text {th }}$ Edition. AWS, 2018. Print ISBN 978-1-64322014-7. PDF ISBN 978-1-64322-015-4.

Dr. Yassin Mustafa Ahmed; Dr. Hameed D. Lafta; Azhin Abdullah Abdul Rahman, BSc; Barzan Talib Salih, BSc 


\section{EXPERIMENTÁLNÍ STUDIE VÝKONNOSTI ZÁKLADNÍCH KOVŮ A SVAŘOVACÍ LINKY \\ LPG LAHVÍ POUŽIVANÝCH V DOMÁCNOSTECH V KURDISTÁNU}

Zkapalněný ropný plyn (propan nebo butan) je bezbarvá kapalina bez zápachu, která se snadno vypaří na plyn. Pro detekci netěsnosti bývá aromatizována. Zkapalněný ropný plyn je skladován a zpracováván jako kapalina pod tlakem uvnitř tlakových lahví, které jsou testovány, zda odpovídají normě.

Výzkum se zabývá trvanlivostí svařování a provedením základního kovu u lahví používaných v domácnostech $\mathrm{v}$ Kurdistánu. Pokusy byly prováděny na třech typech standardních lahví a na netvarované desce. $Z$ každé tlakové lahve a z netvarované desky se odeberou tři vzorky pro zkoušku tahem, ohybem a zkoušku tvrdosti podle norem ISO 6892-2016 a standardy ASME včetně analýzy chemického složení. Získané hodnoty jsou porovnány se standardem.

\section{EXPERIMENTELLE STUDIE ZUR LEISTUNGSFÄHIGKEIT VON GRUNDMETALLEN UND ZUR SCHWEISSLINIE VON LPG-FLASCHEN, WIE SIE IN HAUSHALTEN IN KURDISTAN VERWENDUNG FINDEN}

Verflüssigtes Erdölgas (Propan oder Butan) ist eine farb- und geruchlose Flüssigkeit, welche leicht in den gasförmigen Zustand übergeht. Zur Detektion von Undichtigkeiten wird sie aromatisiert. Das verflüssigte Erdölgas wird als Flüssigkeit unter Druck in Druckflaschen gelagert, welche getestet werden, ob sie der Norm entsprechen.

Die Untersuchung befasst sich mit der Haltbarkeit des Schweißens und der Ausführung des Grundmetalls bei den Flaschen, wie sie in Haushalten in Kurdistan verwendet werden. Die Versuche wurden an drei Typen von Standardflaschen und an der ungeformten Platte durchgeführt. Jeder Druckflasche und jeder ungeformten Platte werden drei Proben entnommen für einen Versuch zur Zug- und Biegungsfestigkeit sowie für eine Härteprobe gemäß den Normen ISO 6892-2016 und für den Standard ASME inklusive einer Analyse der chemischen Zusammensetzung. Die dabei gewonnen Werte werden mit dem Standard verglichen.

\section{EKSPERYMENTALNE BADANIE WYDAJNOŚCI PODSTAWOWYCH METALI I LINII SPAWALNICZEJ BUTLI LPG UŻYWANYCH W GOSPODARSTWACH DOMOWYCH W KURDYSTANIE}

Skroplony gaz ropopochodny (propan lub butan) to bezbarwna, bezzapachowa ciecz, która łatwo odparowuje w gaz. W celu wykrycia nieszczelności bywa aromatyzowana. Skroplony gaz ropopochodny magazynowany i przetwarzany jest jako ciecz pod ciśnieniem w butlach gazowych, które są testowane pod kątem spełnienia normy.

Badania dotyczą trwałości spawania i wykonania podstawowego metalu w przypadku butli używanych w gospodarstwach domowych w Kurdystanie. Badania przeprowadzano na trzech typach standardowych butli oraz nieformowanej płycie. Z każdej butli gazowej i nieformowanej płyty pobierane są trzy próbki do badania poprzez ciągnięcie, zginanie i badania twardości wg norm ISO 6892-2016 oraz standardów ASME wraz z analizą składu chemicznego. Uzyskane wartości porównywane są ze standardem. 